\title{
THE MUCH-HOLZMANN SERUM REACTION IN INSANITY *
}

\author{
A. J. ROSANOFF, M.D. \\ KINGS PARK, N. Y.
}

While the present trend in psychiatry seems to be mainly in the direction of psychogenic causes in the etiology of the so-called functional insanities, yet from time to time cases are reported or in other ways facts are brought to light which would indicate that the toxic theory of the origin of these conditions is, at least for the present, not to be definitely discarded.

In a brief preliminary communication published a short time ago H. Much describes a new serum reaction which he found to be almost specific for dementia præcox and manic-depressive insanity. This reaction is based on the alleged power possessed by the serum in cases of these conditions of inhibiting the hemolytic action of cobra venom on human red blood corpuscles.

With the collaboration of W. Holzmann he examined the blood in four hundred cases, including, on the one hand, various forms of insanity and, on the other hand, many different physical diseases without mental disturbances, and found this reaction always present in cases of manicdepressive insanity and dementia præcox, regarded as such in the strictly limited classical sense, according to Kraepelin; he also found it in some cases of epilepsy with periodically recurrent mental disturbances; further, he found it in sane persons belonging to families in which insanity existed.

These remarkable results led me to apply this reaction in a series of cases of various forms of insanity at the Kings Park State Hospital, and, for the purposes of control and comparison, in a number of normal persons.

The technic of the reaction, as described by Much and Holzmann, is as follows: 0.35 c.c. of serum is mixed with 0.25 c.c. of a $1: 5000$ solution of cobra venom; to this is added 0.5 c.c. of a 10 per cent. suspension of human blood corpuscles (prepared by allowing blood to flow into normal salt solution containing 2 per cent. of sodium citrate, washing the cor-

* I am indebted to Dr. H. Noguchi, of the Rockefeller Institute for Medical Research, for the impulse to apply the Much-Holzmann reaction in the cases cited in this paper and for invaluable assistance in making the hemolytic tests.

1. Much, H.: Eine Reaktion im Blute von Geisteskranken. München med. Wehnschr., May 18, 1909. 
puscles twice with normal salt solution and finally making a suspension of the desired strength); this mixture is placed in the incubator for two hours and then in the refrigerator for twenty-two hours, at the end of which time the reading is taken.

I have found it convenient to modify the technic to a slight extent. The stock solution of cobra venom was prepared in the manner suggested by Much and Holzmann, namely, by making a 2 per cent. solution of the dried venom in distilled water and then adding an equal volume of glycerin; this solution was preserved by the addition of a few drops of chloroform and was further protected against putrefaction by being kept in the refrigerator. For use it was diluted with normal salt solution until a solution of the strength of 1:5000 was obtained. The cobra venom which $I$ used was from a specimen in possession of Dr. $H$. Noguchi of the Rockefeller Institute; by titration this specimen of venom was found to be so actively hemolytic that the relative quantity of the solution employed in the reaction had to be reduced to a little over onehalf of that employed by Much and Holzmann. The proportions of the other ingredients in the reaction-serum and suspension of blood corpuscles-were not changed, but their absolute quantities were reduced in order to avoid taking unnecessarily large quantities of blood.

From 1 to 1.5 c.c. of blood taken from the lobe of the ear supplied the amount of serum which $I$ used in the reaction, namely, 0.2 c.c.; to this was added 0.08 c.c. of the 1:5000 solution of cobra venom and 0.3 c.c. of blood corpuscle suspension. In the control tubes 0.2 c.c. of normal salt solution was used in place of serum.

Complete hemolysis occurred in the control tube almost always before it occurred in any of the other tubes, so that it became evident that practically all serums had some slight power of inhibiting the hemolytic action of cobra venom on human blood corpuscles. On the other hand, complete inhibition of hemolysis did not occur in a single instance. Thus the reaction became merely a test of the relative degree of this inhibiting power possessed by a given serum. Therefore, I took the readings, as suggested by Much and Holzmann, at the end of twenty-four hours (two hours in the incubator and twenty-two hours in the refrigerator), on thoroughly shaking the tubes. In taking the readings in this way I found no difficulty in distinguishing between a strongly positive reaction and a distinctly negative one; but in many instances of moderate inhibition of hemolysis I was unable to make the distinction satisfactorily; for this reason, in tabulating my findings, I counted as positive $(+)$ all cases in which the mixture in the tubes on shaking showed complete 
opacity, as slightly positive or doubtful $(+)$ all cases in which there was opacity with a distinct laked appearance, and as negative (-) all eases in which the tubes showed any degree of transparency.

The cases used in this investigation were carefully selected from the large amount of such material that is available at this hospital with a view to excluding all but perfectly typical cases in which the diagnoses were as nearly certain as possible; thus in all the cases of general paresis the clinical diagnosis had been corroborated by lumbar puncture. To this there were, however, five exceptions: in four cases there were symptom-complexes resembling manic-depressive insanity, but running a chronic course with no remissions or alternating phases; these cases form in the table of findings a separate group designated "chronic psychoses allied to manic-depressive insanity"; and one case, which presented a clinical picture of dementia præcox, showed, in addition, some evidences of organic brain disease, and appears in the table as "psychosis allied to dementia pracox."

The specimens of serums assumed to be normal were obtained from officers and employees at this hospital, who kindly consented to give some of their blood not only for the purpose of furnishing the serum, but also for preparing the suspension of blood corpuscles used in the reaction. I take this opportunity of acknowledging my indebtedness to them.

As will be seen from the figures in the table, the serums of some of the apparently normal persons showed a positive reaction. The statement of Much, to the effect that this reaction may be found in the serums of sane persons belonging to families tainted with insanity, has already been referred to. I regret to have found it impracticable to inquire into the matter of insane heredity in my cases. The following table shows my findings :

Table 1.-Mech-Holzasaxy Reaction

\begin{tabular}{|c|c|c|c|}
\hline Mental Disorders. & + & + & - \\
\hline Dementia præcox & 22 & $\overline{2}$ & 14 \\
\hline$\ldots \ldots \ldots \ldots \ldots \ldots 35$ & 5 & 3 & 27 \\
\hline Epilepsy with insanity............. 12 & 2 & 4 & 6 \\
\hline Polyneuritic psychosis $\ldots \ldots \ldots \ldots \ldots \ldots \ldots$ & I & 1 & 6 \\
\hline Manic depressive insanity . . . . . . . . . 15 & 0 & 1 & 14 \\
\hline Involution melancholia $\ldots \ldots \ldots \ldots \ldots \ldots \ldots$ 10 & 1 & 0 & 9 \\
\hline Senile dementia & 0 & 1 & 10 \\
\hline Arteriosclerotic brain disease ........... & 0 & 3 & 3 \\
\hline Infantile cerebral palsy $\ldots \ldots \ldots \ldots \ldots \ldots \ldots, 5$ & 1 & 2 & 2 \\
\hline Paranoic condition $\ldots \ldots \ldots \ldots \ldots \ldots \ldots \ldots 2$ & 0 & $\cdot 0$ & 2 \\
\hline$\ldots \ldots \ldots \ldots \ldots \ldots$ & 0 & 0 & 1 \\
\hline Chronic phychoses allied to manic depressive & & & \\
\hline$\ldots \ldots \ldots \ldots \ldots$ & 2 & 1 & I \\
\hline Psychosis allied to dem. prac $\ldots \ldots \ldots \ldots \ldots, 1$ & 0 & 0 & 1 \\
\hline No psychosis $\ldots \ldots \ldots \ldots \ldots \ldots \ldots \ldots \ldots \ldots .37$ & 3 & $\overline{5}$ & 29 \\
\hline
\end{tabular}


In 109 of the above cases the serum was examined also for the Wassermann reaction. In order to determine whether there is any relationship between the Much-Holzmann reaction and the Wassermann reaction I have tabulated my results.

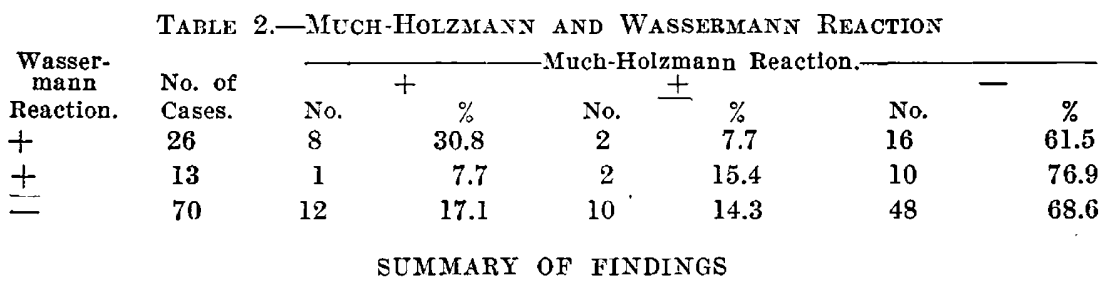

1. Practically all human serums possess the power, in a more or less pronounced degree, of inhibiting the hemolytic action of cobra renom on human blood corpuscles. ${ }^{2}$

2. A comparatively high degree of this power, which constitutes the basis of Much and Holzmann's reaction, is not strictly specific for any psychosis, being found with greater or less frequency in almost all psychoses and in the blood of a considerable percentage of persons who are apparently normal ( 8.1 per cent. in the series cited in this paper).

3. This reaction was present in more than half of my series of cases (5\%.9 per cent.) of dementia præcox. As it appears to be much more common in this condition than in any other, it may prove to be a diagnostic aid; it would seem that the presence of this reaction in a psychosis should add, in the consideration of the diagnosis, some degree of probability in favor of dementia præcox.

4. Of a series of fifteen typical cases of manic-depressive insanity not one gave a positive reaction, and in only one was the reaction doubtful, being clearly negative in all the rest. I might add here that two of the patients had recovered from their psychosis when their blood was examined.

5. There is apparently no relationship between the Wassermann reaction and the Much-Holzmann reaction.

2. For a complete presentation of the subject of venom hemolysis see Noguchi : Snake Venoms, chap. xvi (published by the Carnegie Institution, Washington, D. C., 1909). 